\title{
ICT Policy Outcomes for National Development: The Place of Knowledge Integration and Management in Nigerian Higher Education
}

\author{
Chinyere Onyemaechi Agabi ${ }^{1}$, Comfort Nkogho Agbor ${ }^{2}$, Nwachukwu Prince Ololube ${ }^{1}$ \\ ${ }^{1}$ Department of Educational Foundations and Management, Faculty of Education, Ignatius Ajuru University of Education, Port Harcourt, \\ Rivers State, Nigeria \\ ${ }^{2}$ Department of Environmental Education, Faculty of Education, University of Calabar, Calabar, Cross River State, Nigeria
}

Email address:

chinyereagabi@yahoo.com (C. O. Agabi), commyspaco@yahoo.com (C. N. Agbor) ololubeprince@yahoo.com (N. P. Ololube)

\section{To cite this article:}

Chinyere Onyemaechi Agabi, Comfort Nkogho Agbor, Nwachukwu Prince Ololube. ICT Policy Outcomes for National Development: The Place of Knowledge Integration and Management in Nigerian Higher Education. American Journal of Networks and Communications. Vol. 4, No. 5, 2015, pp. 104-111. doi: 10.11648/j.ajnc.20150405.11

\begin{abstract}
The prologues of Information Communication Technology (ICT) usage including its integration and diffusion kicked off a new era in educational processes and has fundamentally changed the conventional methods of teaching and learning in higher education institutions (HEIs) around the world, and have transformed contemporary processes of teaching and learning experiences of both lecturers and students. The debates here are made with reference to (1) the contexts of ICT and knowledge integration (2) the challenges of ICT usage and knowledge integration, and (3) ICT policy outcomes and national development. A qualitative research method was adopted; the use of document and observation were indispensable part of the methods for data gathering. The study found that the lofty hopes, keenness and enthusiasm for ICT and knowledge integration and management are obstructed as the nation is faced with inadequacies in essential ICT infrastructures and services such as telecommunication services, electricity, incompetent ICT personnel, inadequate funding, poor economic situation, poverty, high ICT literacy rate and so on. However, there is an ongoing moves and development to ensure effective ICT knowledge integration and management in education resources in Nigeria and Africa higher education institutions. This novel study recommends that higher education should become expansive, positive and proactive actors in ICT knowledge integration and management in teaching, learning and research for academics, non-academics to foster admirable academic environment aimed at meeting national development. This learned debate has implication for education practitioners, curriculum developers and designers, policy makers, planners and the government.
\end{abstract}

Keywords: ICT, Knowledge Integration, Management, Diffusion, Higher Education, Policies, National Development

\section{Introduction}

Information Communication Technology (ICT) is a complex network of connections that presents an increasingly expanding collection of innovative services that have key financial consequences in the processes of knowledge integration and management in higher education and maybe adjudged to be very important for national development (Ifinedo \& Ololube, 2007). The processes that lead to knowledge integration according to Ololube, Kpolovie, Amaele, Amanchukwu and Briggs (2013) is the use of computer-based (Ololube, 2009) and web-based learning technological (Ifinedo, 2006) tools adopted by institutions of higher education in organising and the processing of information and communication needs of such organisations.

Promoting and developing a knowledge society through computer-based and web-based learning technological tools is one of the strategic plans that is increasingly adopted in recent times by knowledge advancement institutions around the world who wish to progress and support economic growth for national development (Ololube, Ubogu \& Egbezor, 2007). In particular, higher education institutions worldwide are saddled with the responsibility of growing in importance as agencies for the development of knowledge (Akuegwu, Anijaobi-Idem \& Ekanem, 2011). As a result, a number of countries, particularly those in the west have been proactive towards developing strategies to drive efforts aimed 
at providing institutions of higher education the opportunity to achieve knowledge parity for their citizens (Department of Education and Skills, 2011). However, despite advances in ICT, higher education institutions in the Third World are masqueraded with complex problems especially in their academic programmes in reaching the goals of promoting the development of knowledgeable society (Johnson, 2007).

Global efforts at proactively creating knowledge society through ICT include components of computer hardware and software, network connectivity and several other devices that are essential to achieving effective knowledge management. The components include but are not limited to audio, camera, e-mail, facsimile (Fax), internet, intranet, main-frame computer, minicomputer, micro-computer, photography, teleconference, video, websites, word processing computer etc. (Nwafor, 2005). According to Lopez (2003) ICT has provided innovative opportunities for teaching, learning, research and administration in higher education.

The ICT literacy rate in many institutions of higher learning in the Third World has been a craze of major concerns and has transformed how we see other counties in the global contexts (Mac-Ikemenjima, 2005). ICT literacy rate in this context is the competence (familiarity, skills and ability) of students, academic and non-academic staff to identify, explore actual fact, presents and diffuse information in order to assemble knowledge and develop the spirit of learning to be critical and self-critical, and learn to create knowledge significant to a theme of study (Ololube, 2012). To be able to create knowledge is the ability to generate new knowledge on the basis of one's own experiences and constructing knowledge where none is available (Mohanan, 2005). This has given rise to progresses in our conducts in life because ICT has transformed and impacted on educational methodologies in higher education globally (Pena-Bandalaria, 2007; Richardson et al., 2015). However, it is pertinent to note that the revolution taking place in higher education is not widespread and there is the need to strengthen ICT penetrations to reach a larger percentage of students, faculty and non-faculty in our institutions of higher education (Ifinedo, 2005, 2006). Therefore, knowledge integration and management approaches (Bellinger et al., 2004) (see figure 1) are extremely essential to guarantee successful national development of Nigeria's economy and society. These approaches involve the process of including novel information into an existing body of knowledge using multiple approaches. The processes entail the determination of how new information and the existing knowledge interrelate to each other, how existing body of knowledge should be made to other to accommodate new information, and how new information should be structured to reflect existing knowledge (Cárdenas, Al-Jibouri, Halman \& van Tol, 2013).

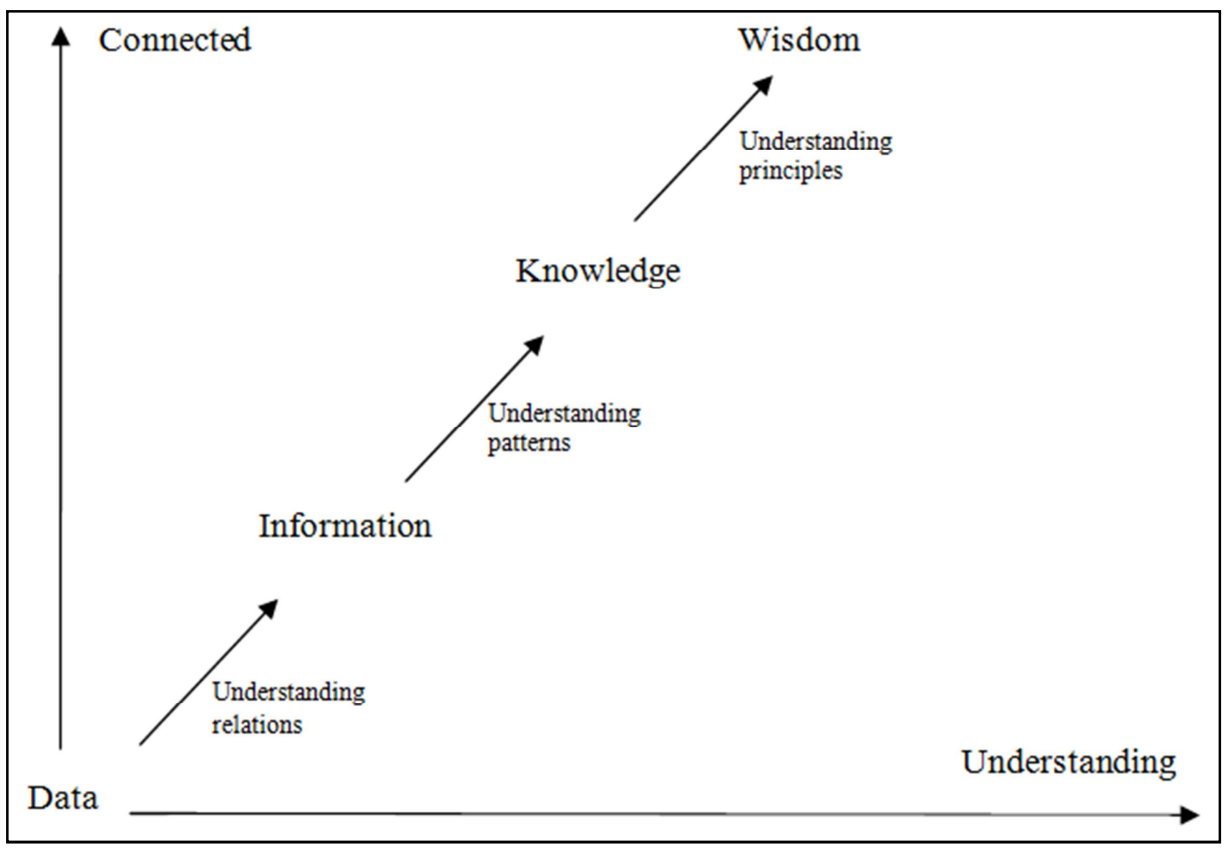

Figure 1: Knowledge hierarchy (Bellinger et al., 2004).

The knowledge hierarchies presented above can be explained thus:

- Data: incoherent collection of facts about a phenomenon that has little basic interest;

- Information: evolves when relationships between the connecting facts are established and understood;

- Knowledge: this is when patterns of relationships are determined, identified and understood;
- Wisdom: judging to produce understanding where there was no prior understanding;

- Understanding: recognition and logical synthesis of novel knowledge from existing knowledge.

The academic landscape of Nigeria's higher education includes traditional $\mathrm{f} 2 \mathrm{f}$ teaching-learning and the distance education processes, along its research processes. Additionally, it includes the certificate and degree 
programmes and courses, theses, disseminations and academic publications; the libraries and information services; higher education administration and management. The $\sigma^{\text {th }}$ edition of the Nigerian national policy on education (FRN, 2013) perceived higher education as post-secondary education system which is given in universities, Polytechnics, Colleges of Education and Monotechnics, as well as those organisations offering correspondence courses. The Federal Republic of Nigeria (FRN, 2013) through its national policy on education stated that the goals of higher education shall be:

- To acquire both physical intellectual skills which will enable individuals to be self-reliant and useful members of society;

- To contribute to nationwide development through high level germane manpower training;

- To expand and inculcate proper value for the survival of the individual and society;

- To enlarge the intellectual capacity capability of individuals to understand and appreciate local and external environments;

- To forge and cement national unity; and

- To encourage and encourage scholarship and community service;

- To encourage national and international understanding and interaction.

The Federal Republic of Nigeria through its higher education institutions shall pursue these goals to make for favourable contributions to national development. And ICT is seen as an indispensable constituent towards the move for knowledge integration (Oyovwe-Tinuoye \& Adogbeji, 2013). Nonetheless, ICT diffusion, use and its penetration into research, teaching and learning in higher education are dependent upon the resources availability, which are heavily dependent on government policies and the political environment (Ololube, 2013). However, the policies and political atmosphere has necessitated gaps in addressing innovative ideas, free enterprise, development problems, strategic planning (Meek, et al., 2009) and the digital divide in Nigerian academic landscape especially in higher education. Scholars (e.g., Mac-Ikemenjima, 2005; Ifinedo, 2005; Ololube, 2009; Cárdenas, Al-Jibouri, Halman \& van Tol, 2013) belief that ICT has a lot to offer towards knowledge integration, creation and management. However, the Nigeria government has failed to deliver on that front in line with international best practices, because a great deal of time and efforts has been and is still endowed in developing policy guidelines, instead of effective implementation of ICT programmes aimed at elevating and positioning Nigeria in the global academic community (Ololube et al., 2013).

According to professional colleagues and in line with an academic work entitled "Active Learning Application of Technology Tools and Services to Increase Student Achievement in Online and Blended Learning Environments in Higher Education Institutions" by Ololube (2015), this learned research however revealed 'significant improvement in the use of ICT tools and blended learning methods to accomplish effective and active academic performance in students and academics. The impact of ICT and blended learning in higher education institutions is evidenced in the changing instructional strategies to improved student academic attainments, which results from more active interactive learning processes'. Nevertheless, the perceptions of the respondents are that the Nigerian government's policy on higher education to enhance ICT usage and integration is still struggling to yield greater positive results as achieved in the west. The study contends that Nigeria's usual place of paying lip service or little attention to empowering higher education must stop if Nigeria is to make headway in its knowledge integration agenda.

To this end, the objective of this paper is to understand perceptions concerning the role of ICT in knowledge integration and management in Nigeria. Despite studies confirming the importance of knowledge integration and management to national and global development (e.g., Agbeja \& Fajemisin, 2008; Sridharan, Tretiakov, \& Kinshuk, 2004), and the perception among some professionals in Nigeria who say ICT is not related to knowledge integration and management. Rather they see knowledge integration to be tied to intelligence, available resources, interest in academic work, and other personality traits as factors that propels knowledge integration and management. As a result, there is need to theoretically ascertain if the factors mentioned by colleagues are responsible for knowledge integration in Nigeria higher education environment. This study attempts to offer new perspectives into the varied factors that support the use of ICT for knowledge integration and management. This study will further address the intellectual gap in understanding the role of ICT in knowledge integration.

\section{Literature Review}

\subsection{The Contexts of ICT, Knowledge Integration and Management}

As humans we are challenged with the need to resolving our daily problem in every life and in academics. The knowledge we possess and the capability to make the most of the appropriate information in our daily lives require meeting some certain task. Taking tactical decision requires sharing of knowledge among colleagues and during teaching and learning processes. Basically, knowledge refers to the understanding an individual has about information and the integration and management of knowledge is a comprehensive process, which includes all the processes that allow for knowledge capitalisation in higher education (Oladejo \& Osofisan, 2011). Information communication technology (ICT) literacy has been recognised to influence the search for relevant information to solve daily and academic problems (Ifinedo \& Ololube, 2007).

The acceptance and use of ICT to boost knowledge integration and management processes is valuable for higher education in positive ways - enhancing and enabling and in negative ways - blocking and frustrating methods. However, 
ICT can increase the knowledge content of the teachinglearning methods and the type of students who graduate from higher education institutions. It can make possible as well as hinder the processes of knowledge integration, acquisition, diffusion, relevance and preservation. The acceptance and use of ICT to enhance and facilitate knowledge integration and management has brought to the centre state the burning need for new policies and methodology towards achieving quality higher education around the world (Omona, van der Weide, \& Lubega, 2010).

ICT fundamentally refers to the application of technology in communication to influence the teachers and learners acquisition of knowledge. It facilitate the achievement of educational goals, benefits the advancement of critical literacy including technological literacy among teachers and students using computer-based teaching and learning methods (CBTL) (Ifinedo, 2005; Ololube, 2009). CBTL improves methods of teaching and learning and makes them more efficient and even more effective; it makes teaching and learning extremely interesting to both the teachers and the learners, it deepens knowledge acquisition for the teachers and learners, but has superior impact on learners. It increases the ability of learners and adds value to knowledge (Ololube et al., 2013). Thus, CBTL improves the quality of information, knowledge integration and management.

\subsection{The Challenges of ICT Usage and Knowledge Integration}

The most recent Global Information Technology Report (GITR) (2015) featured the latest Networked Readiness Index (NRI). NRI assessed the indicators, policies and institutions that facilitates and enables a country to fully influence ICTs for improved competitiveness and knowledge integration. The timing and release of this report is germane when many economies around the world are struggling to make sure that economic growth is equitable and provides benefits for their entire populace. As shown in the GITR (2015) report, ICTs act as a means of social development and transformation by improving access to basic services, enhanced connectivity, creating employment opportunities and knowledge societies. In this year's NRI ranking, Nigeria dropped seven places to rank $119^{\text {th }}$ out of 143 countries. NRI for 2014 was $112^{\text {th }}$ out of 148 countries, while that of 2013 was $113^{\text {th }}$ out of 144 countries. The low ranking is due to several factors as indicated in table 1 below.

Table 2 presents a detailed analysis of the indicators that necessitated Nigeria to be listed amongst the ICT low rank countries. The most important indicators to this study are the $3^{\text {rd }}, 4^{\text {th }}, 5^{\text {th }}, 6^{\text {th }}$, and the $10^{\text {th }}$ pillars. Indices in the $3 \mathrm{rd}$ pillarinfrastructure revealed that the electricity production per Kwh is very low to boost and power ICT tools and services. Nigeria rank 125 out of the 143 countries surveyed as a result of the poor electricity supply in the country. The mobile network coverage per percentage of the population showed that Nigeria ranked 116 out of the 143 countries investigated. What this depicts is that the mobile network coverage for Nigeria is low. Information on the International Internet bandwidth per $\mathrm{kb}$ for each user show that Nigeria ranked very low, in a position of 130 out of the 143 countries evaluated. Same is true of the data for secure Internet servers/million of the population. The revelation is that Nigeria ranked 119 of the 143 countries examined.

Table 1: 2015 Nigeria's Networked Readiness Index.

\begin{tabular}{l|l|l}
\hline Group & Indicators & $\begin{array}{l}\text { Global Ranking / 143 } \\
\text { Countries }\end{array}$ \\
\hline A. & Environment Subindex & 120 \\
& $\begin{array}{l}\text { 1st pillar: Political and regulatory } \\
\text { environment }\end{array}$ & 116 \\
& 2nd pillar: Business and innovation & \\
& environment & 111 \\
B. & Readiness Subindex & 123 \\
& 3rd pillar: Infrastructure & 121 \\
& 4th pillar: Affordability & 104 \\
C. & 5th pillar: Skills & 135 \\
& Usage Subindex & 104 \\
& 6th pillar: Individual usage & 114 \\
& 7th pillar: Business usage & 79 \\
\hline \multirow{2}{*}{ D. } & 8th pillar: Government usage & 95 \\
& Impact Subindex & 104 \\
& 9th pillar: Economic impacts & 81 \\
\hline
\end{tabular}

Source: Global Information Technology Report for Nigeria (2015, p. 213)

Table 2: Detailed Analysis of the $5^{\text {th }}$ Pillar.

\begin{tabular}{ll}
\hline Indicators & $\begin{array}{l}\text { Global Ranking/143 } \\
\text { Countries }\end{array}$ \\
\hline 3rd Pillar: Infrastructure & \\
Electricity production, kWh/capita & 125 \\
Mobile network coverage, \% pop. & 116 \\
Int'l Internet bandwidth, kb/s per user & 130 \\
Secure Internet servers/million pop. & 119 \\
4th pillar: Affordability & \\
Prepaid mobile cellular tariffs, PPP \$/min & 35 \\
Fixed broadband Internet tariffs, PPP \$/month & 118 \\
Internet \& telephony competition, 0-2 (best) & 1 \\
5th Pillar: Skills & \\
Quality of educational system & 121 \\
Quality of math \& science education & 132 \\
Secondary education gross enrollment rate, \% & 125 \\
Adult literacy rate, \% & 108 \\
6 & \\
Mobilar: Individual Usage & \\
Individuals using Internet, \% & 87 \\
Households w/personal computer, & 119 \\
Fixed broadband Internet subs/100 pop & 112 \\
Mobile broadband subs/100 pop & 140 \\
Use of virtual social networks & 98 \\
10th pillar: Social Impacts & 82 \\
Impact of ICTs on access to basic service & 123 \\
Internet access in schools & 111 \\
ICT use \& gov't efficiency & 119 \\
E-Participation Index, 0-1 (best) & 88 \\
\hline
\end{tabular}

Source: Global Information Technology Report for Nigeria (2015, p. 213)

The NRI index for the $4^{\text {th }}$ pillar-affordability indicates that prepaid mobile cellular tariffs for PPP \$/minute shows a great improvement. This means that the population is willing to pay as high as one United State Dollar per minute tariff. Nigeria ranked 118 for its fixed broadband Internet tariffs for PPP \$/month. The result revealed that the fixed broadband 
Internet tariffs for PPP $\$ /$ month is low. On Internet and telephony competition Nigeria was ranked 1 in a $0-2$ (best) rating. This means that Nigeria is comparatively competing moderately fine with its counterparts in the west because Nigeria is one of the fastest emergent telecommunications market in the world.

The $5^{\text {th }}$ NRI indices revealed astonishing results when Nigeria ranked $121^{\text {st }}$ of the 143 countries surveyed based on quality of educational system. This is in the same way true when no Nigerian university was ranked amongst the 1000 best universities in the world. Nigeria was ranked $132^{\text {nd }}$ of the 143 countries examined on quality of math and science education. This result did no portray Nigeria in good light. On secondary education gross enrollment rate per percentage of the population placed Nigeria at a distant $125^{\text {th }}$ position. The adult literacy rate per percentage of the population of Nigeria positioned her in $108^{\text {th }}$ out of the 143 countries surveyed. This low ranking could be deduced that the low ranking is as a result of Nigeria's low ICT penetration.

The Readiness Subindex: 3rd pillar: Infrastructure, 4th pillar: Affordability and 5th pillar: Skills are influence by vandalisation of ICT infrastructure, insecurity and scarce electrical power supply for operations, local participation in key ICT areas, too little skills and enabling environment (Okwuke, 2013) and poverty (Ololube, 2013).

Data for the NRI for the $6^{\text {th }}$ pillar-individual ICT usage revealed that mobile phone subscriptions/100 population placed Nigeria in the $87^{\text {th }}$ position, slightly above half of all the 143 countries surveyed. Individuals using Internet per percent of the population depicts that Nigeria ranked $119^{\text {th }}$ of the 143 countries. Information on households/personal computer revealed that Nigeria was ranked $112^{\text {th }}$. The fixed broadband Internet subscription/100 population is $140^{\text {th }}$ which means Nigeria is among the last four countries that are low in fixed broadband Internet subscription. Mobile broadband subscription/100 population placed Nigeria in $98^{\text {th }}$ position while on the use of virtual social networks; Nigeria was moderately placed at $82^{\text {nd }}$ position.

The NRI index for the 10th pillar-social impacts portray Nigeria very low in the NRI. Nigeria was ranked $123^{\text {rd }}$ of the 143 countries surveyed on the impact of ICTs on access to basic service. The report rated Nigeria low on Internet access in schools at $111^{\text {th }}$ position, and ICT use and government efficiency in $119^{\text {th }}$ place, while the E-Participation index rated on $0-1$ (best), Nigeria was rank $88^{\text {th }}$. These demining results are nothing to write home about considering Nigeria's position as a major player in world economy and Nigeria's ambition to position itself to be one of the top 20 countries in the world by 2020 .

A comparative analysis of three years NRI for selected countries in sub-Saharan Africa and the west revealed that among the sub-Saharan African countries, Nigeria $119^{\text {th }}$, Gambia $108^{\text {th }}$, Ghana $101^{\text {st }}$, Senegal $106^{\text {th }}$, and South Africa $75^{\text {th }}$, was found by the report to have low NRI, meaning that all the indicators for improved ICT penetration are not well developed compared to the countries in the west who topped the list, Germany, Finland, USA, UK, and Sweden ranked $13^{\text {th }}, 2^{\text {nd }}, 7^{\text {th }}, 8^{\text {th }}$, and $3^{\text {rd }}$ respectively in the 2015 NRI. (See table 3 and figure 2 for detail). The overall results indicated that given the existing ICT penetration rate, it may take African countries and indeed Nigeria over 100 years to catch up with the west in her drive for enhanced knowledge integration and management.

Table 3: Networked Readiness Index for Selected Countries.

\begin{tabular}{llll}
\hline Country/Year & $\mathbf{2 0 1 3}$ & $\mathbf{2 0 1 4}$ & $\mathbf{2 0 1 5}$ \\
\hline Nigeria & 113 & 112 & 119 \\
Gambia & 98 & 107 & 108 \\
Ghana & 95 & 96 & 101 \\
Senegal & 107 & 114 & 106 \\
South Africa & 70 & 70 & 75 \\
Germany & 13 & 12 & 13 \\
Finland & 1 & 1 & 2 \\
USA & 9 & 7 & 7 \\
UK & 7 & 9 & 8 \\
Sweden & 3 & 3 & 3 \\
\hline
\end{tabular}

Source: Global Information Technology Report for Nigeria (2015)

\subsection{ICT Policy Outcomes for National Development}

The Federal Executive Council of Nigeria approved a national ICT policy in 2007 with the creation of the National Information Technology Development Agency (NITDA). NITDA was charged with the responsibility of developing and implementing ICT policies (NITDA, 2015). However, voices from several quarters (e.g., Okwuke, 2013; Osuagwu, 2015) are of the view that NITDA's mandate is long overdue for review due to advances in global ICT use, integration and diffusion. NITDA interventions in promoting inclusive development are in policy areas like ICT for Development (ICT4D), National ICT Policy, National Software Policy (NSP), Local Content Guidelines, National e-Government Master Plan, States ICT Policy/Strategic Plan and Open Data Development Initiative (see figure 3) aimed to develop innovative ICT policies to drive nationwide development. NITDA has failed in its ICT action plan and roadmap for the nation, this is evidence from the Global Information Technology Report for Nigeria (2015) because ICT4D and other policies have failed to impel ICT facilities, use and integration in the country.

On another front, the former president of Nigeria (Dr. Goodluck Ebele Jonathan) in 2011 appointed a Minister into the new Nigerian Ministry of Communication Technology. The President's after consultations with ICT stakeholders, set up an Adhoc Committee to harmonize the diverse policies for the different sectors in the ICT landscape including telecommunications. The committee was charged with the responsibility of balancing and harmonizing all existing guiding principle and policies in the ICT sector into a single ICT policy.

Notwithstanding the efforts by the Adhoc Committee and NITDA to drive nationwide development following multiple interventions, facts shows that the inadequate or the nonattendance and deficiencies of well thought policies and the existing situation in the ICT penetration in Nigeria has widened the digital gap between Nigeria a developing 
countries and the developed west (Okwuke, 2013). Countries with enhanced and increased access to ICT and those who apply ICT extensive in inclusive manner are able to get hold of the advantages of globalization. Conversely countries with laughable ICT infrastructure end up not joining the race for globalization. The truth remains that ICTs provide efficiency in global educational management systems, increase faculty and students' productivity and opens up novel opportunities that drives growth, development and improvement in every sector of the economy, particularly in knowledge integration and management.

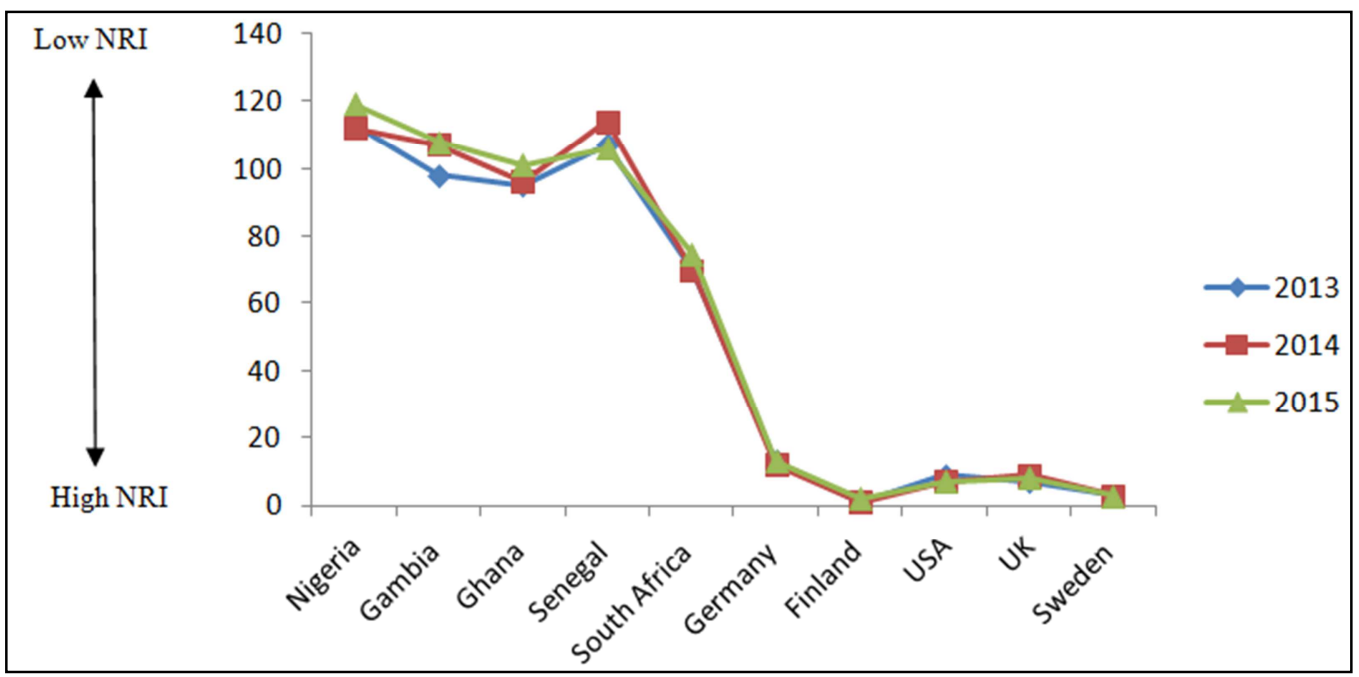

Figure 2: Line representation of some selected countries NRI for 2013, 2014 and 2015.
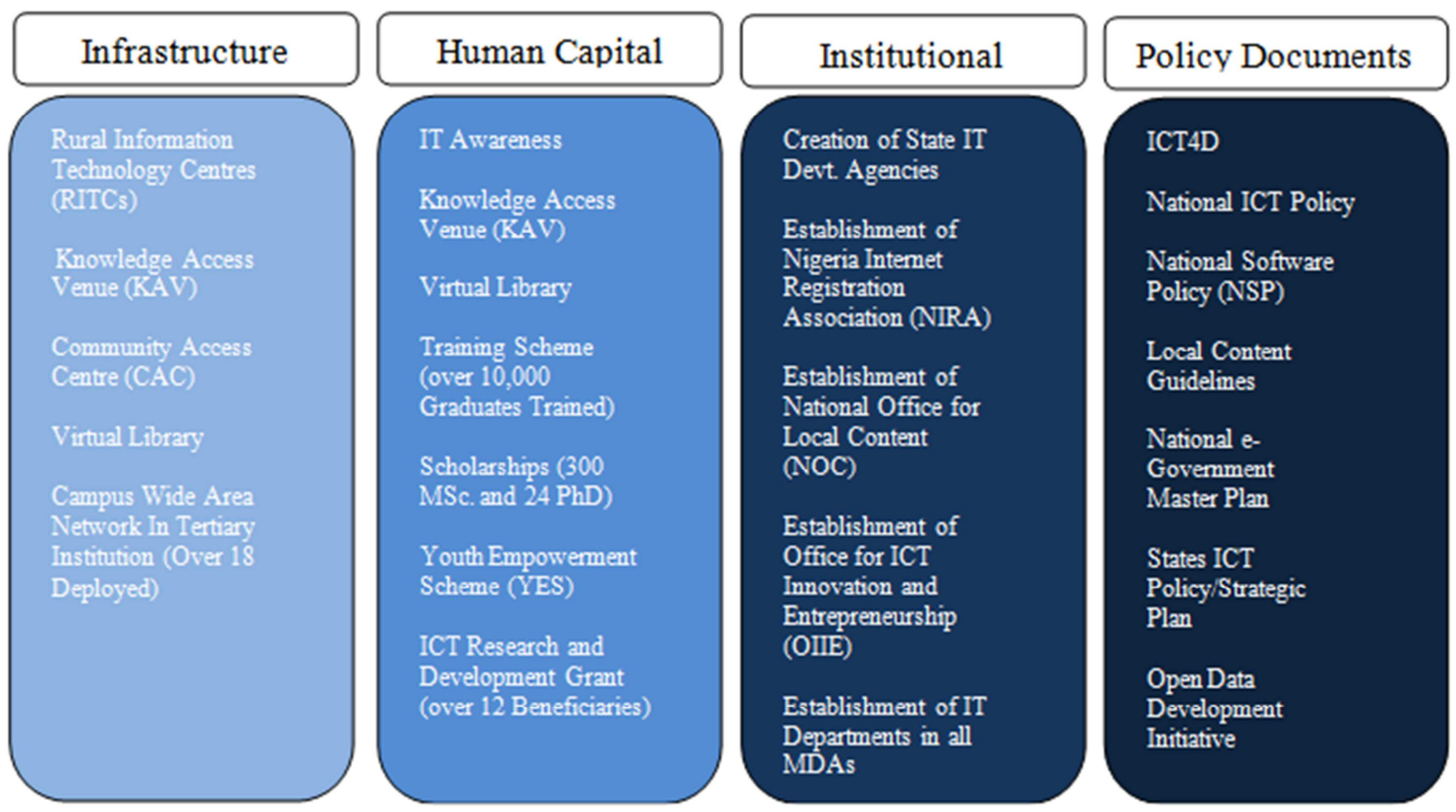

Source: National Information Technology Development Agency (NITDA) (2015)

Figure 3: NITDA interventions in promoting inclusive development.

\section{Discussion/Conclusions}

In this paper, it is evidence that ICT enhances knowledge integration and management in higher education. The several outstanding issues that will bridge the current existing gaps between the requirements and the challenges facing the acceptance and use of ICT to enhance knowledge integration and management in higher education was addressed. This work highlights the relationships between ICT and knowledge integration and management in higher education systems.

This unique study realises that in spite of the unparalleled mobile penetration and the substantial market prospects and potentials, Nigeria is far from being near the digital age if plausible and credible policy measures are not immediately established, because ICT services and products are changing by the day. The effort put so far does not guarantee success; 
what matters is the implementation and the speed of incorporating new ICT trends into Nigeria's higher education (Osuagwu, 2015).

According to the Global Information Technology Report (2015) on NRI, less than $40 \%$ of the world population enjoys access to the Internet in spite of the fact that more than half of the population now own a mobile phone. Africa is ranked as one of the highest in mobile phone penetration but the report found that the lack of access to Internet is depriving many African higher education institutions the opportunity to take full advantage of blended learning and web-based learning and services to enhance knowledge integration and management for development to strive.

At this point, African and indeed Nigerian higher education industries can make massive strides in connecting more of their students, academic and non-academic staff to bring about positive knowledge integration by improving its Networked Readiness Indices. Government policies and the political and regulatory environment will show commitment to bring the benefit of ICTs to our knowledge institutions. Africa and indeed Nigeria needs to prioritise ICT usage, knowledge, skills, and development if it has to benefit from the new knowledge economy and the competences needed to stimulate national development.

The 2015 Global Information Technology report suggests that investment in ICT and education infrastructure; including creating and promoting an enabling environment and competition through sound higher education policies and regulation will correct the imbalance in Nigeria's academic landscape in Higher education. Therefore, genuine policies and strategies that will strengthen digital transformation are direly needed at this stage of our national development.

Not until Nigeria formulates enabling policies, regulations and laws that will improve access to ICT infrastructure in all spheres of life. The building of an ever-present broadband infrastructure, supporting device ownership for all Nigerians, encouraging local content development, stimulating transparency, efficiency and productivity in government and citizen engagement, Nigeria's aim of multiple policies will go to waste.

\section{References}

[1] Agbeja, O., \& Fajemisin, D. O. (2008). Knowledge Management: Strategy for Corporate Survival and Sustainable Global Development. Journal of Knowledge Management Practice, 9(2). Retrieved August 28, 2015 from http://www.tlainc.com/articl157.htm.

[2] Akuegwu, B. A., Anijaobi-Idem, F. N., \& Ekanem, E. E. (2011). Higher Institution Students' Access to Information and Communications Technology in Nigeria: Management Imperatives for Labour Market Preparations. European Journal of Business and Management, 3(11), 29-40.

[3] Bellinger, G., Castro, D., \& Mills, A. (2004) Data, Information, Knowledge and Wisdom. Retrieved July 30, 2015 from http://www.systems-thinking.org/dikw/dikw.htm.
[4] Cárdenas, I., Al-Jibouri, S. H. S., Halman, J. I. M., \& van Tol, F. A. (2013) Capturing and integrating knowledge for managing risks in tunnel works. Risk Analysis, 33(1), 92-108.

[5] Department of Education and Skills (2011). National Strategy for Higher Education to 2030 - Report of the Strategy Group. Retrieved August 18, 2015 from http://www.hea.ie/sites/default/files/national_strategy_for_hig her_education_2030.pdf.

[6] Federal Republic of Nigeria (FRN) (2013). National Policy on Education $6^{\text {th }}$ edition. Lagos: NERC Press.

[7] Global Information Technology Report (2015). Networked Readiness Index. Retrieved August 30, 2015 from http://reports.weforum.org/global-information-technologyreport-2015/downloads/.

[8] Ifinedo, P. \& Ololube, N. P. (2007). A Discourse on the Problems, Prospects, and Progress of Distance Education in a Developing Country. In E. P. Bailey (Ed.) Focus on Distance Education Developments (pp. 183-194). New York, NY: Nova Science Publishers.

[9] Ifinedo, P. (2005). Measuring Africa's e-readiness in the global networked economy: A nine country data analysis. International Journal of Education and Development using Information and Communication Technology, 1(1), 53-71.

[10] Ifinedo, P. (2006). Acceptance and Continuance Intention of Web-Based Learning Technologies (WLT) among University Students in a Baltic Country. The Journal of Information Systems in Developing Countries, 23(6), 1-20.

[11] Johnson, S. O. (2007). Enhancing quality in higher education through information and communication technology in Nigeria. In J. B. Babalola, G. O. Akpa, A. O. Ayeni, \& S. O. Adedeji (Eds.) Access, Equity and Quality in Higher Education (pp. 505-512). Ibadan: NAEAP Publication.

[12] Lopez, V. (2003). An exploration of the use of information technologies in the college classroom. College Quarterly, 6(1) Retrieved August 15, 2015 from http://www.collegequarterly.ca/2003-volo6-num01fall/lopes.html.

[13] Mac-Ikemenjima, D. (2005). e-Education in Nigeria: Challenges and Prospects. Paper Presented at the 8th UN ICT Task Force Meeting April 13-15, 2005 Dublin, Ireland.

[14] Meek, V. L., Teichler, U., \& Kearney, M. (Eds.) (2009). Higher Education, Research and Innovation: Changing Dynamics. Report on the UNESCO Forum on Higher Education, Research and Knowledge 2001-2009. Kassel: International Centre for Higher Education Research.

[15] Mohanan, K. P. (2005) 'Assessing qualities of teaching in higher education', Centre for Development of Teaching and Learning (CDTL). Retrieved September 12, 2015 from http://www.cdtl.nus.edu.sg/publications/assess/who.htm.

[16] NITDA (2015). NITDA Interventions in promoting Inclusive Development. Retrieved September 12, 2015 from http://www.ncs.org.ng/wp-content/uploads/2015/08/NITDAPresentation.pdf.

[17] Nwafor, S. O. (2005). Information Technology: A modern tool for the administration of universities in Rivers State. Nigerian Journal of Educational Administration and Planning, 5(2), 184-188. 
[18] Okwuke, E. (2013). New ICT policy as catalyst for national development. Retrieved August 2, 2015 from http://dailyindependentnig.com/2013/04/new-ict-policy-ascatalyst-for-national-development/.

[19] Oladejo, B. O., \& Osofisan, A. O. (2011). A Conceptual Framework for Knowledge Integration in the Context of Decision Making Progress. African Journal of Computer \& ICT, 4(2), 25-32.

[20] Ololube, N. P. (2009) Computer communication and ICT attitude and anxiety among higher education students. In A. Cartelli \& M. Palma (Eds). Encyclopedia of Information and Communication Technology, (pp. 100-105). Hershey, PA: Information Science Reference DOI: 10.4018/978-1-59904845-1.ch014.

[21] Ololube, N. P. (2012). Sociology of education and society: an interactive approach. Owerri: SpringField Publishers.

[22] Ololube, N. P. (2013). Evaluating the usage and integration of ITs and ISs in teacher education programs in a sprouting nation. Mediterranean Journal of Social Sciences, 4(16), 6372. DOI:10.5901/mjss.2013.v4n16p63.

[23] Ololube, N. P. (2015). Active Learning Application of Technology Tools and Services to Increase Student Achievement in Online and Blended Learning Environments in Higher Education Institutions. In N. P. Ololube, P. J. Kpolovie, \& L. N. Makewa (Eds.), Handbook of Research on Enhancing Teacher Education with Advanced Instructional Technologies (pp. 109-129). DOI: 10.4018/978-1-4666-81620.ch006.

[24] Ololube, N. P., Kpolovie, P. J., Amaele, S., Amanchukwu, R. N., \& Briggs, T. (2013). Digital Natives and Digital Immigrants: A study of Information Technology and Information Systems (IT/IS) Usage between Students and Faculty of Nigerian Universities. International Journal of Information and Communication Technology Education, 9(3), 42-64. DOI: 10.4018 /jicte.2013070104.
[25] Ololube, N. P., Ubogu, A. E., \& Egbezor, D. E. (2007). ICT and Distance Education Programs in a Sub-Saharan African Country: A Theoretical Perspective. Journal of Information Technology Impact, 7(3), 181-194.

[26] Omona, W., van der Weide, T., \& Lubega, J. (2010). Using ICT to Enhance Knowledge Management in Higher Education A Conceptual Framework and Research Agenda. International Journal of Education and Development using Information and Communication Technology, 6(4), 83-101.

[27] Osuagwu, P. (2015). Nigeria drops in Networked Readiness ranking. Retrieved August 31, 2015 from http://www.vanguardngr.com/2015/06/nigeria-drops-innetworked-readiness-ranking/.

[28] Oyovwe-Tinuoye, G., \& Adogbeji, B. O. (2013). Information Communication Technologies (ICT) as an Enhancing Tool in Quality Education for Transformation of Individual and the Nation. International Journal of Academic Research in Business and Social Sciences, 3(4), 21-32.

[29] Pena-Bandalaria, M. D. (2007). Impact of ICTs on Open and Distance Learning in a Developing Country Setting: The Philippine experience. International Review of Research in Open and Distance Learning, 8(1), 1-15.

[30] Richardson, J. C., Koehler, A. A., Besser, E. D., Caskurlu, S., Lim, J., \& Mueller, C. M. (2015). Conceptualizing and Investigating Instructor Presence in Online Learning Environments. International Review of Research in Open and Distributed Learning, 16(3), 256-297.

[31] Sridharan, B., Tretiakov, A., \& Kinshuk, S. (2004), Application of Ontology to Knowledge Management in Web based Learning. In L. Kinshuk, C. K. Sutinen, E. Sampson, D. Aedo, L. Uden, and E. Kahkonen (Eds.), Proceedings of the $4^{\text {th }}$ IEEE International Conference on Advanced Learning Technologies (pp. 663-665), August 30-Sept 1, 2004, Joensuu, Finland. Los Alamitos, CA: IEEE Computer Society. 